OPEN ACCESS

Edited by:

Lesley Ann Smyth,

University of East London,

United Kingdom

Reviewed by:

Bruce Milne Hall,

University of New South Wales,

Australia

Dominic Boardman,

BC Children's Hospital

Research Institute,

Canada

*Correspondence: Margarita Dominguez-Villar m.dominguez-villar@imperial.ac.uk

Specialty section:

This article was submitted to Immunological Tolerance and Regulation,

a section of the journal

Frontiers in Immunology

Received: 31 January 2021 Accepted: 27 April 2021

Published: 14 May 2021

Citation:

Selck $C$ and Dominguez-Villar $M$ (2021) Antigen-Specific Regulatory

$T$ Cell Therapy in Autoimmune

Diseases and Transplantation.

Front. Immunol. 12:661875. doi: 10.3389/fimmu.2021.661875

\section{Antigen-Specific Regulatory T Cell Therapy in Autoimmune Diseases and Transplantation}

\author{
Claudia Selck and Margarita Dominguez-Villar* \\ Faculty of Medicine, Imperial College London, London, United Kingdom
}

Regulatory $T$ (Treg) cells are a heterogenous population of immunosuppressive $T$ cells whose therapeutic potential for the treatment of autoimmune diseases and graft rejection is currently being explored. While clinical trial results thus far support the safety and efficacy of adoptive therapies using polyclonal Treg cells, some studies suggest that antigen-specific Treg cells are more potent in regulating and improving immune tolerance in a disease-specific manner. Hence, several approaches to generate and/or expand antigen-specific Treg cells in vitro or in vivo are currently under investigation. However, antigen-specific Treg cell therapies face additional challenges that require further consideration, including the identification of disease-relevant antigens as well as the in vivo stability and migratory behavior of Treg cells following transfer. In this review, we discuss these approaches and the potential limitations and describe prospective strategies to enhance the efficacy of antigen-specific Treg cell treatments in autoimmunity and transplantation.

Keywords: regulatory T cells, Tregs, antigen-specific Tregs, autoimmune disease (AD), therapy, transplantation

\section{INTRODUCTION}

Treg cells play an essential role in the maintenance of immune homeostasis by inhibiting pathological responses towards self-antigens and controlling potentially harmful inflammatory reactions following infections. While different $\mathrm{T}$ cell populations with immunosuppressive capacity have been described in recent years including type 1 regulatory $\mathrm{T}(\mathrm{Tr} 1)$ cells and $\mathrm{T}$ helper 3 (Th3) cells $(1,2), \mathrm{CD}^{+} \mathrm{CD} 127$ $\mathrm{CD} 25^{\text {high }} \mathrm{T}$ cells that express the transcription factor forkhead box P3 (FOXP3) remain the most studied Treg subset to date and thus, will be the main focus of this review. In healthy individuals, FOXP $3^{+}$Treg cells are generated both in the thymus (tTreg) upon intermediate avidity interaction of developing thymocytes with self-peptides (3) and in the periphery (pTreg) during antigen encounter of conventional naive $\mathrm{CD}^{+} \mathrm{T}$ cells in tolerogenic environments, such as the presence of transforming growth factor beta (TGF- 3 ) and interleukin-2 (IL-2) $(4,5)$. Although specific biomarkers that allow the distinction between tTreg and pTreg cells are currently not available, it is assumed that the antigen specificities of these Treg subsets differ substantially due to their distinct developmental origin $(6,7)$. The $\mathrm{T}$ cell receptor (TCR) repertoire of tTreg cells is skewed toward autoantigen recognition and hence, they predominantly maintain self-tolerance by preventing immune responses against the body's own tissues and organs (8). In contrast, pTreg cells mainly recognize non-self-antigens derived from commensal bacteria, infectious pathogens or ingested food and thus, sustain mucosal tolerance, 
inhibit inflammation-induced tissue damage and avert allergic reactions (5, 9-11). Importantly, various critical questions about the maintenance and function of these antigen-specific Treg cells remain unanswered, involving their in vivo cellular targets, the molecular pathways triggering their activation and the underlying mechanisms controlling their suppressive function.

Considering the crucial functions of $\mathrm{FOXP}^{+}$Treg cells in maintaining a healthy state, it is not surprising that defects in their biology can lead to detrimental disruptions of immune homeostasis. In particular, multiple preclinical and human studies have demonstrated that a number of Treg-specific defects are associated with the development of several autoimmune disorders (AID) such as type 1 diabetes (T1D) (12-14), rheumatoid arthritis (RA) (15, 16), multiple sclerosis (MS) (17-19), systemic lupus erythematosus (SLE) (20) and psoriasis $(21,22)$. These Tregspecific defects include reduced proliferative and migratory capabilities $(21,23)$ as well as lower expression levels of essential Treg markers, including FOXP3 and CD25 (24-27). Moreover, Treg cells isolated from patients with several AID exhibit impaired immunosuppressive functions associated with reduced expression of anti-inflammatory molecules such as IL-10, cytotoxic T lymphocyte antigen 4 (CTLA-4), T cell immunoglobulin and mucin domain-containing 3 (Tim-3) and indoleamine 2,3dioxygenase (IDO) $(16,28-30)$, and increased production of proinflammatory cytokines such as interferon gamma (IFN- $\gamma$ ) and IL$17(13,19)$. Some studies indicate that these deficiencies are predominantly observed in the naïve Treg compartment which is presumed to be largely comprised of tTreg cells $(18,31)$. Nonetheless, it is still unclear whether defects of Treg cell numbers and/or function in human AID are limited to diseaseassociated antigen-specific Treg cells or affect polyclonal Treg populations since the antigen specificity of impaired Treg cells remains insufficiently characterized.

\section{POLYCLONAL VS. ANTIGEN-SPECIFIC TREG THERAPIES}

While new key factors and mechanisms underlying Treg biology continue being elucidated, Treg cell-based therapies have been proposed to be a promising strategy for the re-establishment of immune tolerance in individuals with AID, allergies or organ transplantation (32-35). These treatments currently involve either the adoptive transfer of in vitro expanded Treg cells, or the administration of immunomodulatory interventions that promote the expansion and/or function of Treg cells in vivo (Figure 1). Notably, both of these applications have the potential to promote Treg-mediated immune regulation in a polyclonal or antigen-specific manner with each harboring their own advantages and limitations.

The success of adoptive Treg cell therapies depends on multiple critical factors, including the optimal source of Treg cells, appropriate cell isolation and expansion procedures as well as optimal cell dose and number of infusions administered. First early-phase clinical trials investigating the safety of autologous or allogeneic Treg transfer demonstrated good toxicity profiles in patients with T1D (32, 36-38), MS (39), Crohn's disease (33), graft versus host disease (GvHD) (40-42) and kidney/liver transplantation $(34,43-46)$. In addition, some of these interventions induced signs of disease improvement which supported the investigation of treatment efficacy in larger trials (36-38, 41, 46). Importantly, while these initial human studies adopted somewhat comparable cell enrichment and culture protocols, all of them utilized polyclonal Treg subsets that exhibit a plethora of different TCR specificities. The potential therapeutic benefit of polyclonal Treg population infusion relies on bystander immunosuppression which allows regulation by activated Treg cells through antigen-independent processes (47). Since polyclonal Treg cells undergo extensive activation and expansion in vitro prior to adoptive transfer, it is possible that they are capable of implementing this bystander effect. Therefore, a number of ongoing clinical studies are using polyclonal Treg cells for the treatment of AID including T1D (NCT02772679, NCT03444064), ulcerative colitis (NCT04691232) and Pemphigus (NCT03239470). However, growing evidence from animal models indicates that antigen-specific Treg cells may be more efficient in controlling pathological immune responses in a disease-specific manner (Table 1) (48-64). This is likely due to the migration of infused Treg cells towards tissues of cognate antigen exposure (49, 63) leading to more potent and localized control of inflammation with reduced risks of broad immunosuppression and associated adverse events. Moreover, the enhanced trafficking of antigenspecific Treg cells to target tissues presumably allows the administration of lower Treg cell numbers than polyclonal approaches, potentially facilitating the obtention of these cell numbers in standard in vitro expansion protocols. Nevertheless, the purification and expansion of disease-relevant antigen-specific Treg cells remains technically challenging because of their very low frequency in the peripheral blood (65). Therefore, current efforts are focusing on the generation of antigen-specific Treg cells in vitro by transformation of antigen-specific effector $\mathrm{T}$ (Teff) cells into cells with suppressive capacity (66-68), or genetic insertion of synthetic antigen receptors with disease-relevant antigenic specificities into isolated Treg populations $(53,64,69)$ (Figure 1D).

\section{GENERATION OF ANTIGEN-SPECIFIC TREG CELLS BY ANTIGEN-SPECIFIC EFFECTOR T CELL ENGINEERING}

Similar to the development of pTreg cells in vivo several studies have demonstrated that both murine and human Treg cells can be generated from naïve $\mathrm{CD} 4^{+} \mathrm{T}$ cells in vitro when they are stimulated in the presence of TGF- $\beta$ and IL-2 (induced Treg, iTreg) $(66,70)$. Hence, isolated antigen-specific effector T cells (Teff) could serve as a useful source to generate antigen-specific iTreg cells for adoptive cell therapy. However, it has become clear that the phenotype and function of iTreg cells is not properly maintained under inflammatory conditions (71-73). This is clinically relevant as iTreg cells might be able to regain their pro-inflammatory characteristics in vivo and contribute to an 


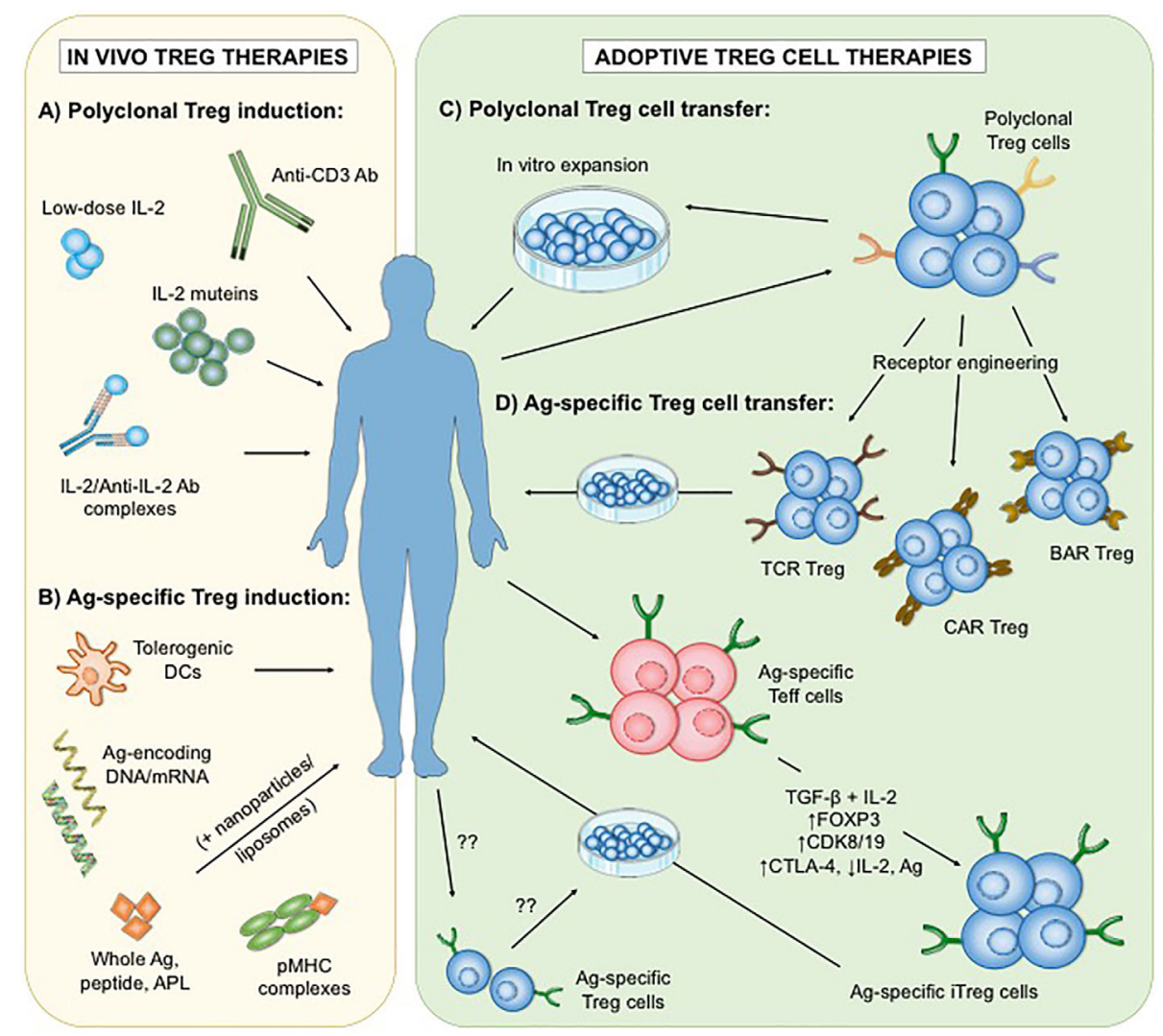

FIGURE 1 | Different approaches of polyclonal and antigen-specific Treg cell-based therapies. To date, two main strategies have been developed: the administration of immunomodulatory agents that enhance the number and/or function of Treg cells in vivo (A, B), and the adoptive transfer of in vitro expanded Treg cells (C, D). Interventions that increase polyclonal endogenous Treg cells in vivo involve low-dose interleukin-2 (IL-2), mutant IL-2, IL2/Anti-IL-2 Ab complexes as well as selective depletion of Teff cells by Anti-CD3 Ab (A). In contrast, applications of antigen-based treatments could lead to the enhancement of antigen-specific Treg subsets (B). On the other hand, adoptive Treg cell therapies rely on the optimal isolation and expansion of Treg cells in vitro. Thus far, clinical trials in autoimmunity have only utilized expanded polyclonal Treg cell populations (C). However, antigen-specific Treg cells can be generated in vitro (D) by genetic insertion of synthetic receptors (including engineered T cell receptors (TCR), chimeric antigen receptors (CAR) or B cell antibody receptors (BAR)), or by transformation of antigen-specific effector T (Teff) cells into induced Treg (iTreg) cells via stimulation in the presence of transforming growth factor beta (TGF-B) and IL-2, transgenic FOXP3 overexpression, blockade of cyclin-dependent kinase 8 (CDK8) and CDK19 signaling, or a combination of cytotoxic T lymphocyte antigen 4 (CTLA-4) overexpression, IL-2 ablation and antigenic stimulation. The isolation and expansion of endogenous antigen-specific Treg cells remains technically challenging. Ag, antigen; DCs, dendritic cells; $\mathrm{APL}$, altered peptide ligands; $\mathrm{PMHC}$, peptide-major histocompatibility complex.

augmented autoimmune response especially considering the inflammatory environment where they will be re-infused in. Thus, other strategies to re-program Teff lymphocytes into Treg cells have been developed including transgenic overexpression of FOXP3 via lentivirus-based techniques (7478). While several studies demonstrated that FOXP3-transduced Teff cells exhibit Treg-like phenotypes and immunosuppressive functions, the random insertion of FOXP3 at different lentiviral integration sites might entail potential safety risks due to the heterogeneity of the final clinical product. Therefore, more advanced genetic tools, such as CRISPR/Cas9 or TALEN, have been recently utilized to generate FOXP3-expressing Teff cells via homology-directed repair-based gene editing $(52,79)$. Moreover, a CRISPR-based system has been shown to successfully repair the FOXP3 gene in T cells from IPEX (immune dysregulation polyendocrinopathy enteropathy and
X-linked) syndrome patients (79). In addition, recent data have demonstrated the feasibility of generating human antigenspecific Treg cells from tetramer-enriched Teff populations by introduction of a transgenic FOXP3 promoter via TALEN and adeno-associated virus-based editing (52). It is noteworthy that Teff cells can also acquire Treg-like characteristics by FOXP3independent approaches, including blockade of cyclindependent kinase 8 (CDK8) and CDK19 signaling pathways (67), as well as by a combination of CTLA-4 overexpression, IL-2 ablation and antigenic stimulation (80). All of these strategies were able to confer immunosuppressive functions to both naïve and activated Teff cells which retained their anti-inflammatory properties in vivo when transferred into different mouse models of autoimmunity $(52,67,80)$. Nonetheless, it remains to be determined whether these applications would have clinical utility in human AID. 
TABLE 1 | Pre-clinical studies demonstrating increased efficacy of antigen-specific adoptive Treg cell therapies for AID and transplantation.

\begin{tabular}{|c|c|c|c|}
\hline Disease & Model & Antigen-specific Treg population & Evidence of superior function \\
\hline T1D & $\begin{array}{l}(\mathrm{BDC} 2.5) \\
\text { NOD } \\
\text { mice }\end{array}$ & $\begin{array}{l}\mathrm{CD} 4^{+} \mathrm{CD} 25^{+} \mathrm{T} \text { cells from TCR-transgenic } \\
\mathrm{BDC} 2.5 \text { mice expanded in vitro with } \mathrm{BDC} \\
\text { peptide and NOD DCs }\end{array}$ & $\begin{array}{l}\text { Efficient inhibition of diabetogenic T cell-induced diabetes in NOD mice (no } \\
\text { suppression with polyclonal CD4 }{ }^{+} \mathrm{CD} 25^{+} \text {NOD Treg cells) }\end{array}$ \\
\hline T1D & $\begin{array}{l}(\mathrm{BDC} 2.5) \\
\mathrm{NOD} \\
\text { mice }\end{array}$ & $\begin{array}{l}\mathrm{CD}^{+}{ }^{+} \mathrm{CD} 25^{+} \mathrm{T} \text { cells from TCR-transgenic } \\
\mathrm{BDC} 2.5 \text { mice expanded in vitro with anti- } \\
\mathrm{CD} 3 / \mathrm{CD} 28 \text { beads }\end{array}$ & $\begin{array}{l}\text { Enhanced suppression + reversal of diabetogenic T cell-induced diabetes in } \\
\text { NOD.RAG-/- or NOD CD28-/- mice (only slight delay of disease with 4-fold higher } \\
\text { numbers of polyclonal CD4 } 4^{+} \text {CD25+ NOD Treg cells) }\end{array}$ \\
\hline RA & $\begin{array}{l}\text { DBA1 } \\
\text { mice }\end{array}$ & $\begin{array}{l}\mathrm{CD}^{+} \mathrm{T} \text { cells transduced with FOXP3 and a } \\
\mathrm{TCR} \text { of a CIA-associated T cell clone }\end{array}$ & $\begin{array}{l}\text { Effective inhibition + reversal of CIA (no effect with FOXP3-transduced CD4 }{ }^{+} \mathrm{T} \text { cells } \\
\text { without antigen specificity) }\end{array}$ \\
\hline MS & $\begin{array}{l}(\mathrm{Tg} 4) \\
\text { B10.PL } \\
\text { mice }\end{array}$ & $\begin{array}{l}\mathrm{CD} 4^{+} \mathrm{CD} 25^{+} \mathrm{T} \text { cells from TCR-transgenic } \\
\mathrm{Tg} 4 \text { mice expanded in vitro with anti-CD3/ } \\
\mathrm{CD} 28 \text { beads }\end{array}$ & $\begin{array}{l}\text { Potent inhibition + amelioration of MBP- or PLP-induced EAE (no effect with polyclonal } \\
\text { B10.PL Treg cells) }\end{array}$ \\
\hline MS & $\begin{array}{l}(2 \mathrm{D} 2) \\
\mathrm{C} 57 \mathrm{~B} / / 6 \\
\text { mice }\end{array}$ & $\begin{array}{l}\text { HDR-edited FOXP3-overexpressing T cells } \\
\text { (edTreg) from TCR-transgenic } 2 \text { D2 mice }\end{array}$ & $\begin{array}{l}\text { Better suppression of Teff proliferation in vivo in MOG-induced EAE compared to } \\
\text { polyclonal C57BI/6 edTreg cells }\end{array}$ \\
\hline MS & $\begin{array}{l}\text { C57BI/6 } \\
\text { mice }\end{array}$ & $\begin{array}{l}\text { MOG-specific CAR-engineered } \mathrm{CD} 4^{+} \mathrm{T} \\
\text { cells with transgenic FOXP3 expression }\end{array}$ & $\begin{array}{l}\text { Increased migration into the brain + better control of MOG-induced EAE than MOCK- } \\
\text { treated FOXP3 }{ }^{+} \mathrm{T} \text { cells }\end{array}$ \\
\hline $\begin{array}{l}\text { Autoimmune } \\
\text { Neuropathy }\end{array}$ & $\begin{array}{l}\text { Lewis } \\
\text { rats }\end{array}$ & $\begin{array}{l}\mathrm{CD}^{+} \mathrm{CD} 25^{+} \mathrm{T} \text { cells from rats expanded in } \\
\text { vitro with PNM and IL-2 }\end{array}$ & $\begin{array}{l}\text { Amelioration of PNM-induced EAN (no effects with } \mathrm{CD} 4^{+} \mathrm{CD} 25^{+} \mathrm{T} \text { cells expanded with } \\
\text { irrelevant autoantigen) }\end{array}$ \\
\hline Colitis & $\begin{array}{l}\text { TNP-Tg } \\
\text { BALB/C } \\
\text { mice }\end{array}$ & $\begin{array}{l}\text { CAR-engineered } \mathrm{CD} 4^{+} \mathrm{CD} 25^{+} \text {Treg cells } \\
\text { specific for TNP }\end{array}$ & Protection from TNBS-induced colitis (no effect with control CAR Treg cells) \\
\hline Colitis & $\begin{array}{l}\text { CEABAC } \\
\text { mice }\end{array}$ & $\begin{array}{l}\text { CAR-engineered } \mathrm{CD}^{+}{ }^{+} \mathrm{CD} 25^{+} \text {Treg cells } \\
\text { specific for CEA }\end{array}$ & $\begin{array}{l}\text { Enhanced colon homing + more efficient amelioration of Teff-mediated and AOM-DSS- } \\
\text { induced colitis compared to control CAR Treg cells }\end{array}$ \\
\hline AIG & $\begin{array}{l}(\mathrm{T} \times \mathrm{A} 23) \\
\mathrm{BALB} / \mathrm{c} \\
\text { mice }\end{array}$ & $\begin{array}{l}\text { TGF- } B \text {-induced iTreg cells generated from } \\
\text { CD4 }{ }^{+} T \text { cells of TXA23 mice }\end{array}$ & Prevention of Teff cell-induced AIG (no suppression with polyclonal BALB/c iTreg cells) \\
\hline $\begin{array}{l}\text { Skin } \\
\text { transplantation }\end{array}$ & $\begin{array}{l}\text { BRG } \\
\text { mice }\end{array}$ & $\begin{array}{l}\text { CAR-engineered human } \mathrm{CD} 4^{+} \mathrm{CD} 25^{+} \text {Treg } \\
\text { cells specific for HLA-A2 }\end{array}$ & $\begin{array}{l}\text { Reduced graft injury in a human skin xenograft model compared to polyclonal Treg } \\
\text { cells }\end{array}$ \\
\hline $\begin{array}{l}\text { Skin } \\
\text { transplantation }\end{array}$ & $\begin{array}{l}\text { NRG } \\
\text { mice }\end{array}$ & $\begin{array}{l}\text { CAR-engineered human CD4 } 4^{+} \text {CD25+ Treg } \\
\text { cells specific for HLA-A2 }\end{array}$ & $\begin{array}{l}\text { Superior inhibition of allospecific immune responses than polyclonal Treg cells in } \\
\text { human skin xenograft model }\end{array}$ \\
\hline $\begin{array}{l}\text { Skin } \\
\text { transplantation/ } \\
\text { GvHD }\end{array}$ & $\begin{array}{l}\text { NSG } \\
\text { mice }\end{array}$ & $\begin{array}{l}\text { CAR-engineered human } \mathrm{CD} 8^{+} \text {CD45RC } \\
\text { Treg cells specific for HLA-A2 }\end{array}$ & More potent suppression of immune responses than control CAR Treg cells \\
\hline GvHD & $\begin{array}{l}\text { (OVA Tg) } \\
\text { C57Bl/6 } \\
\text { mice }\end{array}$ & $\begin{array}{l}\text { TGF-ß-induced OVA-specific iTreg cells } \\
\text { generated from CD4 }{ }^{+} \mathrm{T} \text { cells of OT-II mice }\end{array}$ & Better prevention of GvHD than polyclonal iTreg cells \\
\hline
\end{tabular}

Ref.

T1D, type 1 diabetes; NOD, non-obese diabetic; RA, rheumatoid arthritis; MS, multiple sclerosis; AlG, autoimmune gastritis; TCR, $T$ cell receptor; DCs, dendritic cells; CIA, collageninduced arthritis; HDR, homology-directed repair; MOG, myelin oligodendrocyte glycoprotein; MBP, myelin basic protein; PLP, proteolipid protein; EAE, experimental autoimmune encephalomyelitis; CAR, chimeric antigen receptor; PNM, peripheral nerve myelin; EAN, experimental autoimmune neuritis; TNP, 2,4,6-trinitrophenol; TNBS, 2,4,6-trinitrobenzene sulphonic acid; CEA, carcinoembryonic antigen; AOM-DSS, azoxymethane-dextran sodium sulfate; TGF-B, transforming growth factor beta; HLA, human leukocyte antigen; GVHD, graft versus host disease; OVA, ovalbumin.

\section{GENERATION OF ANTIGEN-SPECIFIC TREG CELLS BY GENETIC ENGINEERING}

A different approach to generate antigen-specific Treg cells in vitro involves the alteration of polyclonal Treg specificities by genetic introduction of synthetic receptors, including engineered TCRs and chimeric antigen receptors (CARs). For example, Treg cells transduced with an exogenous TCR isolated from human islet-specific $\mathrm{CD}^{+}{ }^{+} \mathrm{T}$ cell clones possess more potent antigenspecific suppressive capacities than polyclonal Treg populations (64). Furthermore, adoptive transfer of Treg cells engineered with a TCR specific for myelin basic protein can efficiently improve experimental autoimmune encephalitis (EAE) (81). Different reports from animal models of T1D and RA also demonstrate that TCR engineering can be successfully combined with the transduction of FOXP3 in order to convert Teff lymphocytes into immunosuppressive antigen-specific Treglike cells $(68,82)$. Although these preclinical studies are encouraging, the translation of TCR-engineered Tregs into the clinic is somewhat limited by their major histocompatibility complex (MHC) restriction and the need to isolate and identify antigen-specific and disease-relevant TCRs.

On the other hand, the development of chimeric antigen receptors (CARs) enables the generation of engineered Treg cells that recognize their antigen directly (including whole proteins) in a non-MHC restricted manner (83). CARs consist of an extracellular single-chain variable antibody fragment $(\mathrm{scFv})$ fused with an intracellular CD3 activation domain and (potentially multiple) co-stimulation domains. While it has been suggested that integration of the co-stimulatory molecule CD28 is essential for potent CAR Treg functions (84), the optimal design of CAR Treg cells is still under ongoing investigation (85). Nevertheless, based on their successful application and tolerable safety profiles in cancer treatments (86), the transduction of CARs may be considered a promising approach for future clinical administration of antigen-specific 
Treg cells in AID and transplantation. Notably, whereas CARs possess a higher affinity for their cognate antigen than TCRs, data suggest that CARs require a greater density of antigen for their activation $(87,88)$ [reviewed in (89)]. Thus, the use of CAR Treg cells might be more beneficial for clinical settings where the relevant antigen is highly expressed in the target site while TCRengineered Treg cells are potentially more efficacious in diseases associated with low antigen expression levels.

Initial studies in autoimmunity reported that CARengineered Treg cells specific for 2,4,6-trinitrophenol (TNP) can efficiently reduce murine colitis whereas this was not observed with irrelevant CAR Treg cells (55, 90). Similar results were obtained in two different experimental colitis models that utilized CAR Treg cells recognizing carcinoembryonic antigen (CEA) and confirmed the superior immunosuppressive function of CEA-specific Treg cells compared to non-specific control Treg cells. Moreover, histological analysis revealed that only CEA-CAR Treg cells were able to migrate to the inflamed colon of diseased animals (56). Furthermore, myelin oligodendrocyte glycoprotein (MOG)-specific CAR Treg cells have been shown to better control EAE than sham-treated Treg cells. In this study, CAR engineering was combined with the transgenic expression of FOXP3 in $\mathrm{CD}^{+}$Teff cells resulting in MOG-specific immunosuppressive Treg cells that were able to home to the brain, to decrease EAE symptoms and to mediate protection from a second EAE challenge using pertussis toxin and complete Freund's adjuvant (53). In addition, HLA-A2 CAR-expressing $\left(\mathrm{CD}^{+}\right.$or $\left.\mathrm{CD}^{+}\right)$Treg cells have been used in different preclinical studies of skin transplantation demonstrating superior suppression of human skin graft rejection and reduced GvHD in humanized mouse models (58-60). A phase $1 / 2 \mathrm{a}$ trial is currently examining the safety of HLA-A2 CAR-engineered autologous Treg cells in kidney transplantation (NCT04817774).

Strategies utilizing genetically engineered Treg cells with B cell antibody receptors (BARs) are also under ongoing investigation. Instead of the extracellular $s c F v$ used in CARs, BARs contain an antigen or antigen fragment that can be recognized by $B$ cell receptors (BCRs) on inflammatory antibody producing B cells (91). Like CAR Treg cells, BAR Tregs are not MHC restricted and initial results demonstrated potent immunosuppression in mouse models of allergy (92) and hemophilia (69). Finally, although only currently studied in the context of T cells, and not Tregs, chimeric autoantibody receptor (CAAR) engineering could provide an additional approach to directly target autoreactive B cells in AID (93).

\section{IN VIVO TREG CELL-BASED THERAPIES}

While the development and conduction of adoptive Treg cell therapies are costly and laborious, immunomodulatory drugs that target key molecules of Treg maintenance have the potential to improve Treg-mediated immune tolerance in vivo. These treatments can increase the expansion and/or function of polyclonal or antigen-specific Treg subsets depending on the underlying mechanism of action targeted (Figures 1A, B, respectively). Due to the higher expression of CD25 (the alpha chain of IL-2 receptor) on Treg cells compared to Teff cell populations, interventions that promote Treg-specific IL-2 signaling constitute an attractive approach to improve the performance of the whole endogenous Treg cell pool. Nonetheless, because of its wide range of cellular targets including $\mathrm{CD}^{+}$and $\mathrm{CD}^{+}$effector $\mathrm{T}$ cells and natural killer cells, different strategies that avoid bystander activation of these pro-inflammatory subsets have been developed. These include the treatment with low-dose IL-2 (94-96), engineered IL-2 muteins (97-99) and IL-2/IL-2 antibody complexes (100, 101) that predominantly bind to CD25 over CD122 (IL-2R beta chain) and hence, preferentially induce the expansion of Treg population over Teff lymphocytes. Besides IL-2, some studies suggest that multiple other cytokines can promote the induction and/or suppressive function of antigen-specific Treg cells, including IL-4 (102), IL-5 (103), IL-7 (104), IL-12 (105), IL-15 (106) and IFN- $\gamma(107)$. Furthermore, Treg cell homeostasis relies on several other signaling molecules that can be targeted to increase Treg cell performance in vivo, like mammalian target of rapamycin (mTOR) (108), phosphatase and tensin homolog (PTEN) and protein phosphatase 2A (PP2A) (109-111) as well as essential metabolites (e.g. kynurenine and adenosine) (112, 113). The activation of costimulatory [such as tumor necrosis factor receptor 2, TNFR2 (114)] or co-inhibitory receptors including $\mathrm{T}$ cell immunoreceptor with Ig and ITIM domains (TIGIT) (115) or programmed cell death 1 (PD-1) (116), predominantly expressed on the surface of Treg cells, also have the potential to promote the expansion and/or function of certain Treg subsets more selectively (117). In addition, interventions that preferentially inhibit pathogenic $\mathrm{T}$ cells over Treg cells could be beneficial for the amelioration of autoimmunity or graft rejection. For example, anti-CD3 antibody-mediated improvement of immune tolerance in animal models and patients with AID has been associated with the promotion of Treg cells, partially by selective Teff cell depletion $(118,119)$.

In contrast to these non-specific immunomodulatory therapies, multiple studies suggest that treatment with diseaseassociated antigens can lead to the induction of antigen-specific Treg cells without the risk of broad immunosuppression (120123). Several promising strategies to administer different kinds of antigenic drugs have been shown to inhibit inflammation and disease in preclinical models, but antigen delivery in human studies did not result in the same level of clinical improvements to date, with some of them even leading to worsening of disease (124) (reviewed in (125)). However, some reports detected signs of therapeutic benefit and induced immunotolerance which was associated with the expansion of FOXP3 ${ }^{+}$Treg cells $(122,123)$. In the phase $1 / 2$ Pre-Point trial islet autoantibody-negative children that were genetically at risk to develop T1D received oral insulin for 3-18 months. Interestingly, insulin treatment led to an immune response without unwanted hypoglycemia and induced insulin- and proinsulin-responsive T cells that exhibited characteristics of Treg cells, including FOXP3 expression and 
lack of CD127 and pro-inflammatory cytokines (122). Another study reported improved C-peptide retention and lower insulin use in new-onset T1D patients that were intradermally injected with an immunodominant proinsulin peptide compared to a placebo group (123). This clinical benefit was associated with increased FOXP3 expression in Treg cells and higher levels of IL10 secretion following proinsulin stimulation. It is worth mentioning that antigen administration in animal models of T1D, EAE and collagen-induced arthritis have also resulted in the generation of immunosuppressive IL-10 producing Tr1-like cells $(120,126)$ which might as well be beneficial in human AID $(127,128)$.

\section{CHALLENGES AND IMPROVEMENTS OF ANTIGEN-SPECIFIC TREG THERAPIES}

In order to develop efficient antigen-specific Treg cell-based treatments, disease-associated autoantigens must be well identified and characterized. However, this has not been achieved for many AID, including MS and psoriasis. The choice of the most appropriate antigen is also limited by possible antigen spreading following initial tissue damage, which could hinder the success of therapies that are based on a single antigen. This hurdle could potentially be overcome by targeting multiple self-antigens at the same time (if applicable). Nevertheless, some studies suggest that the exact definition of disease-initiating antigens might not always be necessary as long as the administered intervention leads to the accumulation of activated Treg cells in the affected inflammatory tissues that can induce other immunoregulatory populations in a contact-independent manner. This infectious tolerance' has been observed in a murine model of colitis where TNP-specific CAR Treg cells were able to reduce 2,4,6trinitrobenzene sulphonic acid (TNBS)-induced colitis (55). Localized bystander suppression could be further supported by the transgenic introduction of appropriate surface molecules that are necessary for the migration of activated Treg cells into diseasespecific inflamed sites. While critical signals of Treg cell trafficking to specific tissues remain insufficiently described, previous studies suggest that lymphocytes require the expression of the chemokine receptor CXCR3 in order to home to the brain of MS patients and the pancreatic islets of patients with T1D $(129,130)$. Thus, both efficacy and tolerability of Treg cell administration in these AID could be enhanced by engineering $\mathrm{CXCR}^{+}$tissue-specific Treg cells. On the other hand, patients suffering from psoriasis might benefit from Treg cells expressing the homing receptors CCR4 and cutaneous lymphocyte antigen (CLA) which are necessary for migration into the skin $(131,132)$.

Importantly, uncertainties about the safety of Treg cell infusions and in vivo immunomodulatory interventions still remain and have to be investigated with caution. In particular, the in vivo maintenance and suppressive function of in vitro generated (polyclonal or antigen-specific) Treg populations is an essential factor for the toxicity and efficacy of adoptive cell therapies. While small molecules have been shown to enhance the stability of iTreg cells in vitro, gene editing tools could be utilized to generate Treg cell populations with better resistance to pathological Treg plasticity in inflammatory environments (133). Such potential strategies could include overexpression of FOXP3 as aforementioned, or the knockout of molecules involved in pro-inflammatory signaling pathways present in inflamed tissues of autoimmunity. Notably, although the underlying mechanisms of Treg deficiencies in many AID are not well understood, human studies have reported that cytokines like IL-12 and IL-6 can induce defective Treg functions in vitro $(19,134)$. Hence, ablation of receptors that bind these cytokines might avoid pathological Treg instability following adoptive transfer. Moreover, genetic engineering approaches could be utilized to integrate suicide gene cassettes that can be activated in the case of disease augmentation or severe adverse events caused by harmful immune suppression, such as cancer development or chronic infections (135).

On the other hand, combination therapies of Treg cell transfer with immunomodulatory drugs that reduce autoimmune inflammation or support Treg maintenance could reduce the risk of Treg instability in vivo. Recently, a report demonstrated that combinatory intervention with anti-CD3 antibody enabled improved engraftment of autoantigen-specific Treg cells in the islets of a mouse model of T1D (136). The potential of anti-CD3 combination has been further confirmed in the context of antigenic peptide-based therapies with increased expansion of $\mathrm{FOXP}^{+}$ insulin-specific Treg cells and more potent remission of murine autoimmune diabetes upon nasal administration of proinsulin combined with anti-CD3 treatment (137). In order to minimize the risks of severe side effects caused by immunomodulatory drugs, combination strategies that support the in vivo maintenance of transferred Treg cells more selectively can also be envisioned. For example, engineering of antigen-specific Treg cells with a mutant IL-2 receptor might enable specific potentiation of these infused cells in response to mutant IL-2 administration and thereby, avoid the activation of pro-inflammatory cells by wild type IL-2 (138).

A major obstacle for the development of successful antigenspecific Treg therapies is the substantial level of Treg cell heterogeneity demonstrated by the expression of different lineage-defining transcription factors, such as T-box expressed in T cells (T-bet) (139), GATA-3 (140) or retinoic acid receptorrelated orphan receptor gamma (ROR $\gamma \mathrm{t}$ ) (141), and varying levels of cell surface molecules, including co-inhibitory/costimulatory receptors such as PD-1 (142) and inducible T cell costimulator [(ICOS) (143)], as well as chemokine receptors including CXCR3 and L-selectin [(CD62L) (144-146)]. In addition, Treg cells can mediate their immunosuppressive effects via numerous mechanisms involving the secretion of anti-inflammatory cytokines (147-150), IDO (151) and granzymes $(152,153)$, the actions of the ectoenzymes such as CD39 and CD73 (154) and multiple inhibitory molecules, such as PD-1 (155) and CTLA-4 $(156,157)$. This suggests that at a given time point distinct subpopulations of FOXP ${ }^{+}$Treg cells can be identified in an individual with specialized functions and maintenance requirements which might depend on their developmental origin, the type of immune response they are controlling (Th1, Th2, or Th17-mediated inflammation) (144), 
or the tissue they reside in. Tissue-resident Treg cells have been found in multiple non-lymphoid tissues and organs of healthy individuals (e.g. the skin, gut, lungs, liver, adipose tissue and skeletal muscle) where they can control local inflammation, but also contribute to normal tissue homeostasis during noninflammatory settings via mechanisms that are independent of their immunosuppressive functions (158-160). However, the critical maintenance factors and characteristics of tissueresident Treg cells during health and autoimmunity are still largely unknown. Hence, it is uncertain whether antigen-specific iTreg cells or antigen-based treatments can induce tissue-specific mechanisms of Treg-mediated immune regulation and tissue homeostasis.

Moreover, the underlying causes of numerical and/or functional deficiencies of antigen-specific Treg cells in AID are not well understood and might differ between patients suffering from similar disease symptoms. This is a particularly important factor in the context of autologous adoptive Treg cell therapy as the administration of potentially defective Treg cells might not result in a desired therapeutic outcome. Hence, it is crucial to identify specific Treg defects in an individual and repair affected pathways during the in vitro generation/expansion of antigenspecific Treg cells before adoptive transfer. This personalized strategy could include genetic editing of molecules involved in Treg survival and fitness (such as pathways involved in IL-2 signaling and FOXP3 expression) as well as the insertion of potentially underexpressed chemokine receptors (e.g. CXCR3, CCR4, CLA) in order to increase their capacity to migrate into disease-relevant tissues.

\section{CONCLUSIONS}

In order to develop safe and efficacious antigen-specific Treg therapies, further in-depth studies of the biology of human Treg cells during physiological homeostasis and autoimmune

\section{REFERENCES}

1. Gregori S, Goudy KS, Roncarolo MG. The Cellular and Molecular Mechanisms of Immuno-Suppression by Human Type 1 Regulatory $\mathrm{T}$ Cells. Front Immunol (2012) 3:30. doi: 10.3389/fimmu.2012.00030

2. Chen Y, Kuchroo VK, Inobe J, Hafler DA, Weiner HL. Regulatory T Cell Clones Induced by Oral Tolerance: Suppression of Autoimmune Encephalomyelitis. Science (1994) 265:1237-40. doi: 10.1126/science.7520605

3. Jordan MS, Boesteanu A, Reed AJ, Petrone AL, Holenbeck AE, Lerman MA, et al. Thymic Selection of CD4+CD25+ Regulatory T Cells Induced by an Agonist Self-Peptide. Nat Immunol (2001) 2:301-6. doi: 10.1038/86302

4. Zheng SG, Wang J, Wang P, Gray JD, Horwitz DA. IL-2 is Essential for TGF-beta to Convert Naive CD4+CD25-Cells to CD25+Foxp3+ Regulatory T Cells and for Expansion of These Cells. J Immunol (2007) 178:2018-27. doi: 10.4049/jimmunol.178.4.2018

5. Coombes JL, Siddiqui KR, Arancibia-Carcamo CV, Hall J, Sun CM, Belkaid Y, et al. A Functionally Specialized Population of Mucosal CD103+ Dcs Induces Foxp3+ Regulatory T Cells Via a TGF-beta and Retinoic Acid-Dependent Mechanism. J Exp Med (2007) 204:1757-64. doi: 10.1084/jem.20070590

6. Pacholczyk R, Ignatowicz H, Kraj P, Ignatowicz L. Origin and T Cell Receptor Diversity of Foxp3+CD4+CD25+ T Cells. Immunity (2006) 25:249-59. doi: 10.1016/j.immuni.2006.05.016 pathogenesis are needed. This requires new strategies to characterize distinct Treg subsets, better approaches to identify disease-relevant antigens and Treg defects as well as optimized tools to investigate clinical outcomes. In particular, new Treg biomarkers and technologies which can monitor the migratory behavior and function of infused or endogenous Treg cells in vivo are necessary to identify potential pitfalls that might limit therapeutic benefits. Moreover, it is conceivable that patients with AID might require subject-specific Treg-based treatments that rely on the identification of the individual's underlying Treg deficiency. Nonetheless, the limitations of autologous Treg cell therapies could be circumvented by the use of allogeneic Treg populations with optimal MHC matching. In addition, the creation of universal Treg donor lines by genetic alterations of MHC molecules constitutes a possible strategy that deserves further investigation (discussed in (161)). Together with the ongoing efforts to develop technologies to optimally engineer human Tregs, future studies on the molecular and cellular mechanisms that control human Treg function, stability and maintenance will be critical to optimize current Treg cell-based treatments and to identify new Treg-specific targets amenable to therapeutic intervention.

\section{AUTHOR CONTRIBUTIONS}

$\mathrm{CS}$ and MD-V wrote the manuscript. All authors contributed to the article and approved the submitted version.

\section{ACKNOWLEDGMENTS}

Figure 1 was generated with material from Servier Medical Art, licensed under a Creative Commons Attribution 3.0 Unported License. (http://smart.servier.com/).

7. Fazilleau N, Bachelez H, Gougeon ML, Viguier M. Cutting Edge: Size and Diversity of CD4+CD25high Foxp3+ Regulatory T Cell Repertoire in Humans: Evidence for Similarities and Partial Overlapping With CD4+CD25- T Cells. J Immunol (2007) 179:3412-6. doi: 10.4049/jimmunol.179.6.3412

8. Wyss L, Stadinski BD, King CG, Schallenberg S, McCarthy NI, Lee JY, et al. Affinity for Self Antigen Selects Treg Cells With Distinct Functional Properties. Nat Immunol (2016) 17:1093-101. doi: 10.1038/ni.3522

9. Lathrop SK, Bloom SM, Rao SM, Nutsch K, Lio CW, Santacruz N, et al. Peripheral Education of the Immune System by Colonic Commensal Microbiota. Nature (2011) 478:250-4. doi: 10.1038/nature10434

10. Veiga-Parga T, Sehrawat S, Rouse BT. Role of Regulatory T Cells During Virus Infection. Immunol Rev (2013) 255:182-96. doi: 10.1111/imr.12085

11. Whitehead GS, Wilson RH, Nakano K, Burch LH, Nakano H, Cook DN. Il-35 Production by Inducible Costimulator (ICOS)-Positive Regulatory T Cells Reverses Established IL-17-dependent Allergic Airways Disease. J Allergy Clin Immunol (2012) 129:207-15.e1-5. doi: 10.1016/j.jaci.2011.08.009

12. Brusko TM, Wasserfall CH, Clare-Salzler MJ, Schatz DA, Atkinson MA Functional Defects and the Influence of Age on the Frequency of CD4+ Cd25+ T-cells in Type 1 Diabetes. Diabetes (2005) 54:1407-14. doi: 10.2337/ diabetes.54.5.1407

13. Marwaha AK, Crome SQ, Panagiotopoulos C, Berg KB, Qin H, Ouyang Q, et al. Cutting Edge: Increased IL-17-Secreting T Cells in Children With New- 
Onset Type 1 Diabetes. J Immunol (2010) 185:3814-8. doi: 10.4049/ jimmunol.1001860

14. Haseda F, Imagawa A, Murase-Mishiba Y, Terasaki J, Hanafusa T. Cd4(+) CD45RA(-) FoxP3high Activated Regulatory T Cells are Functionally Impaired and Related to Residual Insulin-Secreting Capacity in Patients With Type 1 Diabetes. Clin Exp Immunol (2013) 173:207-16. doi: 10.1111/ cei. 12116

15. van Roon JA, Hartgring SA, van der Wurff-Jacobs KM, Bijlsma JW, Lafeber FP. Numbers of CD25+Foxp3+ T Cells That Lack the IL-7 Receptor are Increased Intra-Articularly and Have Impaired Suppressive Function in RA Patients. Rheumatol (Oxford) (2010) 49:2084-9. doi: 10.1093/rheumatology/ keq237

16. Cribbs AP, Kennedy A, Penn H, Read JE, Amjadi P, Green P, et al. Treg Cell Function in Rheumatoid Arthritis is Compromised by Ctla-4 Promoter Methylation Resulting in a Failure to Activate the Indoleamine 2,3Dioxygenase Pathway. Arthritis Rheumatol (2014) 66:2344-54. doi: 10.1002/art.38715

17. Korn T, Reddy J, Gao W, Bettelli E, Awasthi A, Petersen TR, et al. MyelinSpecific Regulatory T Cells Accumulate in the CNS But Fail to Control Autoimmune Inflammation. Nat Med (2007) 13:423-31. doi: 10.1038/ nm1564

18. Venken K, Hellings N, Broekmans T, Hensen K, Rummens JL, Stinissen P. Natural Naive CD4+CD25+CD127low Regulatory T Cell (Treg) Development and Function are Disturbed in Multiple Sclerosis Patients: Recovery of Memory Treg Homeostasis During Disease Progression. J Immunol (2008) 180:6411-20. doi: 10.4049/jimmunol.180.9.6411

19. Dominguez-Villar M, Baecher-Allan CM, Hafler DA. Identification of $\mathrm{T}$ Helper Type 1-Like, Foxp3+ Regulatory T Cells in Human Autoimmune Disease. Nat Med (2011) 17:673-5. doi: 10.1038/nm.2389

20. Bonelli M, Savitskaya A, von Dalwigk K, Steiner CW, Aletaha D, Smolen JS, et al. Quantitative and Qualitative Deficiencies of Regulatory T Cells in Patients With Systemic Lupus Erythematosus (SLE). Int Immunol (2008) 20:861-8. doi: 10.1093/intimm/dxn044

21. Soler DC, Sugiyama H, Young AB, Massari JV, McCormick TS, Cooper KD. Psoriasis Patients Exhibit Impairment of the High Potency CCR5(+) T Regulatory Cell Subset. Clin Immunol (2013) 149:111-8. doi: 10.1016/ j.clim.2013.06.007

22. Ma L, Xue H, Gao T, Gao M, Zhang Y. Notch1 Signaling Regulates the Th17/ Treg Immune Imbalance in Patients With Psoriasis Vulgaris. Mediators Inflammation (2018) 2018:3069521. doi: 10.1155/2018/3069521

23. Carbone F, De Rosa V, Carrieri PB, Montella S, Bruzzese D, Porcellini A, et al. Regulatory $\mathrm{T}$ Cell Proliferative Potential is Impaired in Human Autoimmune Disease. Nat Med (2014) 20:69-74. doi: 10.1038/nm.3411

24. Cerosaletti K, Schneider A, Schwedhelm K, Frank I, Tatum M, Wei S, et al. Multiple Autoimmune-Associated Variants Confer Decreased IL-2R Signaling in CD4+ CD25(Hi) T Cells of Type 1 Diabetic and Multiple Sclerosis Patients. PLoS One (2013) 8:e83811. doi: 10.1371/journal.pone. 0083811

25. Maier LM, Lowe CE, Cooper J, Downes K, Anderson DE, Severson C, et al. IL2RA Genetic Heterogeneity in Multiple Sclerosis and Type 1 Diabetes Susceptibility and Soluble Interleukin-2 Receptor Production. PLoS Genet (2009) 5:e1000322. doi: 10.1371/journal.pgen.1000322

26. Hashemi V, Farrokhi AS, Tanomand A, Babaloo Z, Hojjat-Farsangi M, Anvari E, et al. Polymorphism of Foxp3 Gene Affects the Frequency of Regulatory $\mathrm{T}$ Cells and Disease Activity in Patients With Rheumatoid Arthritis in Iranian Population. Immunol Lett (2018) 204:16-22. doi: 10.1016/j.imlet.2018.10.001

27. Long SA, Cerosaletti K, Bollyky PL, Tatum M, Shilling H, Zhang S, et al. Defects in IL-2R Signaling Contribute to Diminished Maintenance of FOXP3 Expression in CD4(+)CD25(+) Regulatory T-cells of Type 1 Diabetic Subjects. Diabetes (2010) 59:407-15. doi: 10.2337/db09-0694

28. Sun H, Gao W, Pan W, Zhang Q, Wang G, Feng D, et al. Tim3(+) Foxp3 (+) Treg Cells Are Potent Inhibitors of Effector T Cells and Are Suppressed in Rheumatoid Arthritis. Inflammation (2017) 40:1342-50. doi: 10.1007/ s10753-017-0577-6

29. Caudy AA, Reddy ST, Chatila T, Atkinson JP, Verbsky JW. CD25 Deficiency Causes an Immune Dysregulation, Polyendocrinopathy, Enteropathy, Xlinked-like Syndrome, and Defective IL-10 Expression From CD4
Lymphocytes. J Allergy Clin Immunol (2007) 119:482-7. doi: 10.1016/ j.jaci.2006.10.007

30. Thiruppathi M, Rowin J, Ganesh B, Sheng JR, Prabhakar BS, Meriggioli MN. Impaired Regulatory Function in Circulating CD4(+)CD25(High)CD127 (Low/-) T Cells in Patients With Myasthenia Gravis. Clin Immunol (2012) 145:209-23. doi: 10.1016/j.clim.2012.09.012

31. Balandina A, Lecart S, Dartevelle P, Saoudi A, Berrih-Aknin S. Functional Defect of Regulatory CD4(+)CD25+ T Cells in the Thymus of Patients With Autoimmune Myasthenia Gravis. Blood (2005) 105:735-41. doi: 10.1182/ blood-2003-11-3900

32. Bluestone JA, Buckner JH, Fitch M, Gitelman SE, Gupta S, Hellerstein MK, et al. Type 1 Diabetes Immunotherapy Using Polyclonal Regulatory T Cells. Sci Transl Med (2015) 7:315ra189. doi: 10.1126/scitranslmed.aad4134

33. Desreumaux P, Foussat A, Allez M, Beaugerie L, Hebuterne X, Bouhnik Y, et al. Safety and Efficacy of Antigen-Specific Regulatory T-cell Therapy for Patients With Refractory Crohn's Disease. Gastroenterology (2012) 143:1207-17.e2. doi: 10.1053/j.gastro.2012.07.116

34. Sanchez-Fueyo A, Whitehouse G, Grageda N, Cramp ME, Lim TY, Romano M, et al. Applicability, Safety, and Biological Activity of Regulatory T Cell Therapy in Liver Transplantation. Am J Transplant (2020) 20:1125-36. doi: 10.1111/ajt.15700

35. Smaldini PL, Orsini Delgado ML, Fossati CA, Docena GH. Orally-Induced Intestinal Cd4+ CD25+ Foxp3+ Treg Controlled Undesired Responses Towards Oral Antigens and Effectively Dampened Food Allergic Reactions. PLoS One (2015) 10:e0141116. doi: 10.1371/journal.pone.0141116

36. Marek-Trzonkowska N, Mysliwiec M, Dobyszuk A, Grabowska M, Techmanska I, Juscinska J, et al. Administration of CD4+CD25highCD127Regulatory T Cells Preserves Beta-Cell Function in Type 1 Diabetes in Children. Diabetes Care (2012) 35:1817-20. doi: 10.2337/dc12-0038

37. Marek-Trzonkowska N, Mysliwiec M, Dobyszuk A, Grabowska M, Derkowska I, Juscinska J, et al. Therapy of Type 1 Diabetes With CD4(+) CD25(High)CD127-Regulatory T Cells Prolongs Survival of Pancreatic Islets - Results of One Year Follow-Up. Clin Immunol (2014) 153:23-30. doi: 10.1016/j.clim.2014.03.016

38. Marek-Trzonkowska N, Mysliwiec M, Iwaszkiewicz-Grzes D, Gliwinski M, Derkowska I, Zalinska M, et al. Factors Affecting Long-Term Efficacy of T Regulatory Cell-Based Therapy in Type 1 Diabetes. J Transl Med (2016) 14:332. doi: 10.1186/s12967-016-1090-7

39. Chwojnicki K, Iwaszkiewicz-Grzes D, Jankowska A, Zielinski M, Lowiec P, Gliwinski M, et al. Administration of CD4(+)CD25(high)CD127(-)FoxP3 (+) Regulatory T Cells for Relapsing-Remitting Multiple Sclerosis: A Phase 1 Study. BioDrugs (2021) 35:47-60. doi: 10.1007/s40259-020-00462-7

40. Trzonkowski P, Bieniaszewska M, Juscinska J, Dobyszuk A, Krzystyniak A, Marek N, et al. First-in-Man Clinical Results of the Treatment of Patients With Graft Versus Host Disease With Human Ex Vivo Expanded CD4 +CD25+CD127- T Regulatory Cells. Clin Immunol (2009) 133:22-6. doi: 10.1016/j.clim.2009.06.001

41. Brunstein CG, Miller JS, Cao Q, McKenna DH, Hippen KL, Curtsinger J, et al. Infusion of Ex Vivo Expanded T Regulatory Cells in Adults Transplanted With Umbilical Cord Blood: Safety Profile and Detection Kinetics. Blood (2011) 117:1061-70. doi: 10.1182/blood-2010-07-293795

42. Theil A, Tuve S, Oelschlagel U, Maiwald A, Dohler D, Ossmann D, et al Adoptive Transfer of Allogeneic Regulatory $\mathrm{T}$ Cells Into Patients With Chronic Graft-Versus-Host Disease. Cytotherapy (2015) 17:473-86. doi: 10.1016/j.jcyt.2014.11.005

43. Chandran S, Tang Q, Sarwal M, Laszik ZG, Putnam AL, Lee K, et al Polyclonal Regulatory $\mathrm{T}$ Cell Therapy for Control of Inflammation in Kidney Transplants. Am J Transplant (2017) 17:2945-54. doi: 10.1111/ ajt. 14415

44. Sawitzki B, Harden PN, Reinke P, Moreau A, Hutchinson JA, Game DS, et al. Regulatory Cell Therapy in Kidney Transplantation (the ONE Study): A Harmonised Design and Analysis of Seven non-Randomised, Single-Arm, Phase 1/2A Trials. Lancet (2020) 395:1627-39. doi: 10.1016/S0140-6736(20) 30167-7

45. Roemhild A, Otto NM, Moll G, Abou-El-Enein M, Kaiser D, Bold G, et al Regulatory $\mathrm{T}$ Cells for Minimising Immune Suppression in Kidney Transplantation: Phase I/IIa Clinical Trial. BMJ (2020) 371:m3734. doi: 10.1136/bmj.m3734 
46. Harden PN, Game DS, Sawitzki B, Van der Net JB, Hester J, Bushell A, et al. Feasibility, Long-Term Safety, and Immune Monitoring of Regulatory T Cell Therapy in Living Donor Kidney Transplant Recipients. Am J Transplant (2021) 21:1603-11. doi: 10.1111/ajt.16395

47. Thornton AM, Shevach EM. Suppressor Effector Function of CD4+CD25+ Immunoregulatory T Cells is Antigen Nonspecific. J Immunol (2000) 164:183-90. doi: 10.4049/jimmunol.164.1.183

48. Tarbell KV, Yamazaki S, Olson K, Toy P, Steinman RM. Cd25+ Cd4+ T Cells, Expanded With Dendritic Cells Presenting a Single Autoantigenic Peptide, Suppress Autoimmune Diabetes. J Exp Med (2004) 199:1467-77. doi: 10.1084/jem.20040180

49. Tang Q, Henriksen KJ, Bi M, Finger EB, Szot G, Ye J, et al. In VitroExpanded Antigen-Specific Regulatory T Cells Suppress Autoimmune Diabetes. J Exp Med (2004) 199:1455-65. doi: 10.1084/jem.20040139

50. Fujio K, Okamoto A, Araki Y, Shoda H, Tahara H, Tsuno NH, et al. Gene Therapy of Arthritis With TCR Isolated From the Inflamed Paw. J Immunol (2006) 177:8140-7. doi: 10.4049/jimmunol.177.11.8140

51. Stephens LA, Malpass KH, Anderton SM. Curing CNS Autoimmune Disease With Myelin-Reactive Foxp3+ Treg. Eur J Immunol (2009) 39:1108-17. doi: 10.1002/eji.200839073

52. Honaker Y, Hubbard N, Xiang Y, Fisher L, Hagin D, Sommer K, et al. Gene Editing to Induce FOXP3 Expression in Human CD4(+) T Cells Leads to a Stable Regulatory Phenotype and Function. Sci Transl Med (2020) 12: eaay6422-40. doi: 10.1126/scitranslmed.aay6422

53. Fransson M, Piras E, Burman J, Nilsson B, Essand M, Lu B, et al. CAR/ Foxp3-Engineered T Regulatory Cells Target the CNS and Suppress EAE Upon Intranasal Delivery. J Neuroinflamm (2012) 9:112. doi: 10.1186/17422094-9-112

54. Tran GT, Hodgkinson SJ, Carter N, Verma ND, Robinson CM, Plain KM, et al. Autoantigen Specific IL-2 Activated CD4(+)CD25(+)T Regulatory Cells Inhibit Induction of Experimental Autoimmune Neuritis. J Neuroimmunol (2020) 341:577186. doi: 10.1016/j.jneuroim.2020.577186

55. Elinav E, Waks T, Eshhar Z. Redirection of Regulatory T Cells With Predetermined Specificity for the Treatment of Experimental Colitis in Mice. Gastroenterology (2008) 134:2014-24. doi: 10.1053/j.gastro.2008.02.060

56. Blat D, Zigmond E, Alteber Z, Waks T, Eshhar Z. Suppression of Murine Colitis and its Associated Cancer by Carcinoembryonic Antigen-Specific Regulatory T Cells. Mol Ther (2014) 22:1018-28. doi: 10.1038/mt.2014.41

57. Huter EN, Stummvoll GH, DiPaolo RJ, Glass DD, Shevach EM. Cutting Edge: Antigen-Specific TGF Beta-Induced Regulatory T Cells Suppress Th17-mediated Autoimmune Disease. J Immunol (2008) 181:8209-13. doi: 10.4049/jimmunol.181.12.8209

58. Boardman DA, Philippeos C, Fruhwirth GO, Ibrahim MA, Hannen RF, Cooper D, et al. Expression of a Chimeric Antigen Receptor Specific for Donor Hla Class I Enhances the Potency of Human Regulatory T Cells in Preventing Human Skin Transplant Rejection. Am J Transplant (2017) 17:931-43. doi: 10.1111/ajt.14185

59. Noyan F, Zimmermann K, Hardtke-Wolenski M, Knoefel A, Schulde E, Geffers R, et al. Prevention of Allograft Rejection by Use of Regulatory $\mathrm{T}$ Cells With an MHC-Specific Chimeric Antigen Receptor. Am J Transplant (2017) 17:917-30. doi: 10.1111/ajt.14175

60. Bezie S, Charreau B, Vimond N, Lasselin J, Gerard N, Nerriere-Daguin V, et al. Human CD8+ Tregs Expressing a MHC-specific CAR Display Enhanced Suppression of Human Skin Rejection and GVHD in NSG Mice. Blood Adv (2019) 3:3522-38. doi: 10.1182/bloodadvances.2019000411

61. Semple K, Yu Y, Wang D, Anasetti C, Yu XZ. Efficient and Selective Prevention of GVHD by Antigen-Specific Induced Tregs Via LinkedSuppression in Mice. Biol Blood Marrow Transplant (2011) 17:309-18. doi: $10.1016 /$ j.bbmt.2010.12.710

62. MacDonald KG, Hoeppli RE, Huang Q, Gillies J, Luciani DS, Orban PC, et al. Alloantigen-Specific Regulatory T Cells Generated With a Chimeric Antigen Receptor. J Clin Invest (2016) 126:1413-24. doi: 10.1172/JCI82771

63. Sagoo P, Ali N, Garg G, Nestle FO, Lechler RI, Lombardi G. Human Regulatory $\mathrm{T}$ Cells With Alloantigen Specificity are More Potent Inhibitors of Alloimmune Skin Graft Damage Than Polyclonal Regulatory T Cells. Sci Transl Med (2011) 3:83ra42. doi: 10.1126/scitranslmed.3002076

64. Hull CM, Nickolay LE, Estorninho M, Richardson MW, Riley JL, Peakman $\mathrm{M}$, et al. Generation of Human Islet-Specific Regulatory T Cells by TCR
Gene Transfer. J Autoimmun (2017) 79:63-73. doi: 10.1016/ j.jaut.2017.01.001

65. Jenkins MK, Moon JJ. The Role of Naive T Cell Precursor Frequency and Recruitment in Dictating Immune Response Magnitude. J Immunol (2012) 188:4135-40. doi: 10.4049/jimmunol.1102661

66. Chen W, Jin W, Hardegen N, Lei KJ, Li L, Marinos N, et al. Conversion of Peripheral CD4+CD25- Naive T Cells to CD4+CD25+ Regulatory T Cells by TGF-beta Induction of Transcription Factor Foxp3. J Exp Med (2003) 198:1875-86. doi: 10.1084/jem.20030152

67. Akamatsu M, Mikami N, Ohkura N, Kawakami R, Kitagawa Y, Sugimoto A, et al. Conversion of Antigen-Specific Effector/Memory T Cells Into Foxp3expressing Treg Cells by Inhibition of CDK8/19. Sci Immunol (2019) 4: eaaw2707-23. doi: 10.1126/sciimmunol.aaw2707

68. Yang SJ, Singh A, Cook P, Honaker Y, Tappen T, Mauk K, et al. Generation of Islet Antigen-Specific Engineered Treg for Use in T1D Therapy Via Homology-Directed Gene Editing of Conventional CD4+ T Cells. J Immunol (2020) 204:237.30-0.

69. Zhang AH, Yoon J, Kim YC, Scott DW. Targeting Antigen-Specific B Cells Using Antigen-Expressing Transduced Regulatory T Cells. J Immunol (2018) 201:1434-41. doi: 10.4049/jimmunol.1701800

70. Freudenberg K, Lindner N, Dohnke S, Garbe AI, Schallenberg S, Kretschmer K. Critical Role of TGF-beta and IL-2 Receptor Signaling in Foxp3 Induction by an Inhibitor of DNA Methylation. Front Immunol (2018) 9:125. doi: 10.3389/fimmu.2018.00125

71. Ohkura N, Hamaguchi M, Morikawa H, Sugimura K, Tanaka A, Ito Y, et al. $\mathrm{T}$ Cell Receptor Stimulation-Induced Epigenetic Changes and Foxp3 Expression are Independent and Complementary Events Required for Treg Cell Development. Immunity (2012) 37:785-99. doi: 10.1016/ j.immuni.2012.09.010

72. Bhela S, Varanasi SK, Jaggi U, Sloan SS, Rajasagi NK, Rouse BT. The Plasticity and Stability of Regulatory T Cells During Viral-Induced Inflammatory Lesions. J Immunol (2017) 199:1342-52. doi: 10.4049/ jimmunol.1700520

73. Beres A, Komorowski R, Mihara M, Drobyski WR. Instability of Foxp3 Expression Limits the Ability of Induced Regulatory T Cells to Mitigate Graft Versus Host Disease. Clin Cancer Res (2011) 17:3969-83. doi: 10.1158/ 1078-0432.CCR-10-3347

74. Fontenot JD, Gavin MA, Rudensky AY. Foxp3 Programs the Development and Function of CD4+CD25+ Regulatory T Cells. Nat Immunol (2003) 4:330-6. doi: 10.1038/ni904

75. Allan SE, Alstad AN, Merindol N, Crellin NK, Amendola M, Bacchetta R, et al. Generation of Potent and Stable Human CD4+ T Regulatory Cells by Activation-Independent Expression of FOXP3. Mol Ther (2008) 16:194-202. doi: 10.1038/sj.mt.6300341

76. Aarts-Riemens T, Emmelot ME, Verdonck LF, Mutis T. Forced Overexpression of Either of the Two Common Human Foxp3 Isoforms can Induce Regulatory T Cells From CD4(+)CD25(-) Cells. Eur J Immunol (2008) 38:1381-90. doi: 10.1002/eji.200737590

77. Beavis PA, Gregory B, Green P, Cribbs AP, Kennedy A, Amjadi P, et al. Resistance to Regulatory $\mathrm{T}$ Cell-Mediated Suppression in Rheumatoid Arthritis can be Bypassed by Ectopic Foxp3 Expression in Pathogenic Synovial T Cells. Proc Natl Acad Sci U S A (2011) 108:16717-22. doi: 10.1073/pnas.1112722108

78. Passerini L, Rossi Mel E, Sartirana C, Fousteri G, Bondanza A, Naldini L, et al. Cd4(+) T Cells From IPEX Patients Convert Into Functional and Stable Regulatory T Cells by FOXP3 Gene Transfer. Sci Transl Med (2013) 5:215ra174. doi: 10.1126/scitranslmed.3007320

79. Goodwin M, Lee E, Lakshmanan U, Shipp S, Froessl L, Barzaghi F, et al. CRISPR-Based Gene Editing Enables FOXP3 Gene Repair in IPEX Patient Cells. Sci Adv (2020) 6:eaaz0571. doi: 10.1126/sciadv.aaz0571

80. Yamaguchi T, Kishi A, Osaki M, Morikawa H, Prieto-Martin P, Wing K, et al. Construction of Self-Recognizing Regulatory $\mathrm{T}$ Cells From Conventional T Cells by Controlling CTLA-4 and IL-2 Expression. Proc Natl Acad Sci U S A (2013) 110:E2116-25. doi: 10.1073/pnas.1307185110

81. Kim YC, Zhang AH, Yoon J, Culp WE, Lees JR, Wucherpfennig KW, et al. Engineered MBP-specific Human Tregs Ameliorate MOG-induced EAE Through IL-2-triggered Inhibition of Effector T Cells. J Autoimmun (2018) 92:77-86. doi: 10.1016/j.jaut.2018.05.003 
82. Wright GP, Notley CA, Xue SA, Bendle GM, Holler A, Schumacher TN, et al. Adoptive Therapy With Redirected Primary Regulatory T Cells Results in Antigen-Specific Suppression of Arthritis. Proc Natl Acad Sci U S A (2009) 106:19078-83. doi: 10.1073/pnas.0907396106

83. Sadelain M, Brentjens R, Riviere I. The Basic Principles of Chimeric Antigen Receptor Design. Cancer Discov (2013) 3:388-98. doi: 10.1158/21598290.CD-12-0548

84. Boroughs AC, Larson RC, Choi BD, Bouffard AA, Riley LS, Schiferle E, et al. Chimeric Antigen Receptor Costimulation Domains Modulate Human Regulatory T Cell Function. JCI Insight (2019) 5:e126194-213. doi: 10.1172/jci.insight.126194

85. Dawson NAJ, Rosado-Sanchez I, Novakovsky GE, Fung VCW, Huang Q, McIver E, et al. Functional Effects of Chimeric Antigen Receptor CoReceptor Signaling Domains in Human Regulatory T Cells. Sci Transl Med (2020) 12:eaaz3866-82. doi: 10.1126/scitranslmed.aaz3866

86. Jain MD, Davila ML. Concise Review: Emerging Principles From the Clinical Application of Chimeric Antigen Receptor T Cell Therapies for B Cell Malignancies. Stem Cells (2018) 36:36-44. doi: 10.1002/stem.2715

87. Bluhm J, Kieback E, Marino SF, Oden F, Westermann J, Chmielewski M, et al. Car T Cells With Enhanced Sensitivity to B Cell Maturation Antigen for the Targeting of B Cell non-Hodgkin's Lymphoma and Multiple Myeloma. Mol Ther (2018) 26:1906-20. doi: 10.1016/j.ymthe. 2018.06.012

88. Huang J, Brameshuber M, Zeng X, Xie J, Li QJ, Chien YH, et al. A Single Peptide-Major Histocompatibility Complex Ligand Triggers Digital Cytokine Secretion in CD4(+) T Cells. Immunity (2013) 39:846-57. doi: 10.1016/j.immuni.2013.08.036

89. Harris DT, Kranz DM. Adoptive T Cell Therapies: A Comparison of T Cell Receptors and Chimeric Antigen Receptors. Trends Pharmacol Sci (2016) 37:220-30. doi: 10.1016/j.tips.2015.11.004

90. Elinav E, Adam N, Waks T, Eshhar Z. Amelioration of Colitis by Genetically Engineered Murine Regulatory T Cells Redirected by Antigen-Specific Chimeric Receptor. Gastroenterology (2009) 136:1721-31. doi: 10.1053/ j.gastro.2009.01.049

91. Parvathaneni K, Scott DW. Engineered FVIII-expressing Cytotoxic T Cells Target and Kill FVIII-Specific B Cells In Vitro and In Vivo. Blood Adv (2018) 2:2332-40. doi: 10.1182/bloodadvances.2018018556

92. Abdeladhim M, Zhang AH, Kropp LE, Lindrose AR, Venkatesha SH, Mitre E, et al. Engineered Ovalbumin-Expressing Regulatory T Cells Protect Against Anaphylaxis in Ovalbumin-Sensitized Mice. Clin Immunol (2019) 207:49-54. doi: 10.1016/j.clim.2019.07.009

93. Ellebrecht CT, Bhoj VG, Nace A, Choi EJ, Mao X, Cho MJ, et al. Reengineering Chimeric Antigen Receptor T Cells for Targeted Therapy of Autoimmune Disease. Science (2016) 353:179-84. doi: 10.1126/ science.aaf6756

94. Hartemann A, Bensimon G, Payan CA, Jacqueminet S, Bourron O, Nicolas $\mathrm{N}$, et al. Low-Dose Interleukin 2 in Patients With Type 1 Diabetes: A Phase 1/2 Randomised, Double-Blind, Placebo-Controlled Trial. Lancet Diabetes Endocrinol (2013) 1:295-305. doi: 10.1016/S22138587(13)70113-X

95. von Spee-Mayer C, Siegert E, Abdirama D, Rose A, Klaus A, Alexander T, et al. Low-Dose Interleukin-2 Selectively Corrects Regulatory T Cell Defects in Patients With Systemic Lupus Erythematosus. Ann Rheum Dis (2016) 75:1407-15. doi: 10.1136/annrheumdis-2015-207776

96. Castela E, Le Duff F, Butori C, Ticchioni M, Hofman P, Bahadoran P, et al. Effects of Low-Dose Recombinant Interleukin 2 to Promote T-regulatory Cells in Alopecia Areata. JAMA Dermatol (2014) 150:748-51. doi: 10.1001/ jamadermatol.2014.504

97. Peterson LB, Bell CJM, Howlett SK, Pekalski ML, Brady K, Hinton H, et al. A Long-Lived IL-2 Mutein That Selectively Activates and Expands Regulatory T Cells as a Therapy for Autoimmune Disease. J Autoimmun (2018) 95:1-14. doi: 10.1016/j.jaut.2018.10.017

98. Spangler JB, Trotta E, Tomala J, Peck A, Young TA, Savvides CS, et al. Engineering a Single-Agent Cytokine/Antibody Fusion That Selectively Expands Regulatory T Cells for Autoimmune Disease Therapy. J Immunol (2018) 201:2094-106. doi: 10.4049/jimmunol.1800578

99. Higginson-Scott N, Otipoby KL, Viney J. Pt101: A Treg Selective Agonist IL2 Mutein Therapy for Autoimmunity. J Immunol (2020) 204:237.16-6.
100. Boyman O, Kovar M, Rubinstein MP, Surh CD, Sprent J. Selective Stimulation of $\mathrm{T}$ Cell Subsets With Antibody-Cytokine Immune Complexes. Science (2006) 311:1924-7. doi: 10.1126/science.1122927

101. Trotta E, Bessette PH, Silveria SL, Ely LK, Jude KM, Le DT, et al. A Human anti-IL-2 Antibody That Potentiates Regulatory T Cells by a Structure-Based Mechanism. Nat Med (2018) 24:1005-14. doi: 10.1038/s41591-018-0070-2

102. Yang W-C, Hwang Y-S, Chen Y-Y, Liu C-L, Shen C-N, Hong W-H, et al. Interleukin-4 Supports the Suppressive Immune Responses Elicited by Regulatory T Cells. Front Immunol (2017) 8:1508-17. doi: 10.3389/ fimmu.2017.01508

103. Tran GT, Hodgkinson SJ, Carter NM, Verma ND, Plain KM, Boyd R, et al. IL-5 Promotes Induction of Antigen-Specific CD4+CD25+ T Regulatory Cells That Suppress Autoimmunity. Blood (2012) 119:4441-50. doi: 10.1182/ blood-2011-12-396101

104. Gratz IK, Truong HA, Yang SH, Maurano MM, Lee K, Abbas AK, et al. Cutting Edge: Memory Regulatory T Cells Require IL-7 and Not IL-2 for Their Maintenance in Peripheral Tissues. J Immunol (2013) 190:4483-7. doi: 10.4049/jimmunol.1300212

105. Verma ND, Hall BM, Plain KM, Robinson CM, Boyd R, Tran GT, et al. Interleukin-12 (IL-12p70) Promotes Induction of Highly Potent Th1-Like Cd4+Cd25+ T Regulatory Cells That Inhibit Allograft Rejection in Unmodified Recipients. Front Immunol (2014) 5:190-201. doi: 10.3389/ fimmu.2014.00190

106. Tosiek MJ, Fiette L, El Daker S, Eberl G, Freitas AA. Il-15-dependent Balance Between Foxp3 and RORgammat Expression Impacts Inflammatory Bowel Disease. Nat Commun (2016) 7:10888. doi: 10.1038/ncomms10888

107. Wang Z, Hong J, Sun W, Xu G, Li N, Chen X, et al. Role of IFN-gamma in Induction of Foxp3 and Conversion of CD4+ Cd25- T Cells to CD4+ Tregs. $J$ Clin Invest (2006) 116:2434-41. doi: 10.1172/JCI25826

108. Zeng H, Yang K, Cloer C, Neale G, Vogel P, Chi H. mTORC1 Couples Immune Signals and Metabolic Programming to Establish T(reg)-cell Function. Nature (2013) 499:485-90. doi: 10.1038/nature12297

109. Apostolidis SA, Rodriguez-Rodriguez N, Suarez-Fueyo A, Dioufa N, Ozcan E, Crispin JC, et al. Phosphatase PP2A is Requisite for the Function of Regulatory T Cells. Nat Immunol (2016) 17:556-64. doi: 10.1038/ni.3390

110. Huynh A, DuPage M, Priyadharshini B, Sage PT, Quiros J, Borges CM, et al. Control of PI(3) Kinase in Treg Cells Maintains Homeostasis and Lineage Stability. Nat Immunol (2015) 16:188-96. doi: 10.1038/ni.3077

111. Shrestha S, Yang K, Guy C, Vogel P, Neale G, Chi H. Treg Cells Require the Phosphatase PTEN to Restrain TH1 and TFH Cell Responses. Nat Immunol (2015) 16:178-87. doi: 10.1038/ni.3076

112. Mezrich JD, Fechner JH, Zhang X, Johnson BP, Burlingham WJ, Bradfield CA. An Interaction Between Kynurenine and the Aryl Hydrocarbon Receptor can Generate Regulatory T Cells. J Immunol (2010) 185:3190-8. doi: 10.4049/jimmunol.0903670

113. Ohta A, Kini R, Ohta A, Subramanian M, Madasu M, Sitkovsky M. The Development and Immunosuppressive Functions of CD4(+) Cd25(+) FoxP3 (+) Regulatory T Cells are Under Influence of the adenosine-A2A Adenosine Receptor Pathway. Front Immunol (2012) 3:190. doi: 10.3389/ fimmu.2012.00190

114. Zou H, Li R, Hu H, Hu Y, Chen X. Modulation of Regulatory T Cell Activity by TNF Receptor Type Ii-Targeting Pharmacological Agents. Front Immunol (2018) 9:594. doi: 10.3389/fimmu.2018.00594

115. Lucca LE, Axisa PP, Singer ER, Nolan NM, Dominguez-Villar M, Hafler DA. TIGIT Signaling Restores Suppressor Function of Th1 Tregs. JCI Insight (2019) 4:e124427-40. doi: 10.1172/jci.insight.124427

116. Stathopoulou C, Gangaplara A, Mallett G, Flomerfelt FA, Liniany LP, Knight D, et al. Pd-1 Inhibitory Receptor Downregulates Asparaginyl Endopeptidase and Maintains Foxp3 Transcription Factor Stability in Induced Regulatory T Cells. Immunity (2018) 49:247-63.e7. doi: 10.1016/ j.immuni.2018.05.006

117. Lucca LE, Dominguez-Villar M. Modulation of Regulatory T Cell Function and Stability by Co-Inhibitory Receptors. Nat Rev Immunol (2020) 20 (11):680-93. doi: 10.1038/s41577-020-0296-3

118. Kuhn C, Weiner HL. Therapeutic anti-CD3 Monoclonal Antibodies: From Bench to Bedside. Immunotherapy (2016) 8:889-906. doi: 10.2217/ imt-2016-0049 
119. Penaranda C, Tang Q, Bluestone JA. Anti-CD3 Therapy Promotes Tolerance by Selectively Depleting Pathogenic Cells While Preserving Regulatory T Cells. J Immunol (2011) 187:2015-22. doi: 10.4049/jimmunol.1100713

120. Clemente-Casares X, Blanco J, Ambalavanan P, Yamanouchi J, Singha S, Fandos C, et al. Expanding Antigen-Specific Regulatory Networks to Treat Autoimmunity. Nature (2016) 530:434-40. doi: 10.1038/nature16962

121. Krienke C, Kolb L, Diken E, Streuber M, Kirchhoff S, Bukur T, et al. A Noninflammatory mRNA Vaccine for Treatment of Experimental Autoimmune Encephalomyelitis. Science (2021) 371:145-53. doi: 10.1126/ science.aay 3638

122. Bonifacio E, Ziegler AG, Klingensmith G, Schober E, Bingley PJ, Rottenkolber M, et al. Effects of High-Dose Oral Insulin on Immune Responses in Children At High Risk for Type 1 Diabetes: The Pre-POINT Randomized Clinical Trial. JAMA (2015) 313:1541-9. doi: 10.1001/ jama.2015.2928

123. Alhadj Ali M, Liu YF, Arif S, Tatovic D, Shariff H, Gibson VB, et al. Metabolic and Immune Effects of Immunotherapy With Proinsulin Peptide in Human New-Onset Type 1 Diabetes. Sci Transl Med (2017) 9:eaaf777988. doi: 10.1126/scitranslmed.aaf7779

124. Bielekova B, Goodwin B, Richert N, Cortese I, Kondo T, Afshar G, et al. Encephalitogenic Potential of the Myelin Basic Protein Peptide (Amino Acids 83-99) in Multiple Sclerosis: Results of a Phase II Clinical Trial With an Altered Peptide Ligand. Nat Med (2000) 6:1167-75. doi: 10.1038/80516

125. Serra P, Santamaria P. Antigen-Specific Therapeutic Approaches for Autoimmunity. Nat Biotechnol (2019) 37:238-51. doi: 10.1038/s41587-019-0015-4

126. Gabrysova L, Nicolson KS, Streeter HB, Verhagen J, Sabatos-Peyton CA, Morgan DJ, et al. Negative Feedback Control of the Autoimmune Response Through Antigen-Induced Differentiation of IL-10-secreting Th1 Cells. J Exp Med (2009) 206:1755-67. doi: 10.1084/jem.20082118

127. Veldman C, Hohne A, Dieckmann D, Schuler G, Hertl M. Type I Regulatory T Cells Specific for Desmoglein 3 are More Frequently Detected in Healthy Individuals Than in Patients With Pemphigus Vulgaris. J Immunol (2004) 172:6468-75. doi: 10.4049/jimmunol.172.10.6468

128. Gianfrani C, Levings MK, Sartirana C, Mazzarella G, Barba G, Zanzi D, et al. Gliadin-Specific Type 1 Regulatory T Cells From the Intestinal Mucosa of Treated Celiac Patients Inhibit Pathogenic T Cells. J Immunol (2006) 177:4178-86. doi: 10.4049/jimmunol.177.6.4178

129. Balashov KE, Rottman JB, Weiner HL, Hancock WW. CCR5(+) and CXCR3(+) T Cells are Increased in Multiple Sclerosis and Their Ligands MIP-1alpha and IP-10 are Expressed in Demyelinating Brain Lesions. Proc Natl Acad Sci U S A (1999) 96:6873-8. doi: 10.1073/pnas.96.12.6873

130. Frigerio S, Junt T, Lu B, Gerard C, Zumsteg U, Hollander GA, et al. Beta Cells are Responsible for CXCR3-mediated T-Cell Infiltration in Insulitis. Nat Med (2002) 8:1414-20. doi: 10.1038/nm1202-792

131. Yu K, Chen Z, Khatri I, Gorczynski RM. CCR4 Dependent Migration of Foxp3+ Treg Cells to Skin Grafts and Draining Lymph Nodes is Implicated in Enhanced Graft Survival in CD200tg Recipients. Immunol Lett (2011) 141:116-22. doi: 10.1016/j.imlet.2011.09.002

132. Issa F, Hester J, Milward K, Wood KJ. Homing of Regulatory T Cells to Human Skin is Important for the Prevention of Alloimmune-Mediated Pathology in an In Vivo Cellular Therapy Model. PLoS One (2012) 7: e53331. doi: 10.1371/journal.pone.0053331

133. Dominguez-Villar M, Hafler DA. Regulatory T Cells in Autoimmune Disease. Nat Immunol (2018) 19:665-73. doi: 10.1038/s41590-018-0120-4

134. Yan Y, Ramanan D, Rozenberg M, McGovern K, Rastelli D, Vijaykumar B, et al. Interleukin-6 Produced by Enteric Neurons Regulates the Number and Phenotype of Microbe-Responsive Regulatory T Cells in the Gut. Immunity (2021) 54:499-513.e5. doi: 10.1016/j.immuni.2021.02.002

135. Jones BS, Lamb LS, Goldman F, Di Stasi A. Improving the Safety of Cell Therapy Products by Suicide Gene Transfer. Front Pharmacol (2014) 5:254. doi: 10.3389/fphar.2014.00254

136. Cabello-Kindelan C, Mackey S, Sands A, Rodriguez J, Vazquez C, Pugliese A, et al. Immunomodulation Followed by Antigen-Specific Treg Infusion Controls Islet Autoimmunity. Diabetes (2020) 69:215-27. doi: 10.2337/db19-0061

137. Bresson D, Togher L, Rodrigo E, Chen Y, Bluestone JA, Herold KC, et al. Anti-CD3 and Nasal Proinsulin Combination Therapy Enhances Remission From Recent-Onset Autoimmune Diabetes by Inducing Tregs. J Clin Invest (2006) 116:1371-81. doi: 10.1172/JCI27191
138. Sockolosky JT, Trotta E, Parisi G, Picton L, Su LL, Le AC, et al. Selective Targeting of Engineered T Cells Using Orthogonal IL-2 Cytokine-Receptor Complexes. Science (2018) 359:1037-42. doi: 10.1126/science.aar3246

139. Koch MA, Tucker-Heard G, Perdue NR, Killebrew JR, Urdahl KB, Campbell DJ. The Transcription Factor T-bet Controls Regulatory T Cell Homeostasis and Function During Type 1 Inflammation. Nat Immunol (2009) 10:595602. doi: 10.1038/ni.1731

140. Wang Y, Su MA, Wan YY. An Essential Role of the Transcription Factor GATA-3 for the Function of Regulatory T Cells. Immunity (2011) 35:337-48. doi: 10.1016/j.immuni.2011.08.012

141. Sefik E, Geva-Zatorsky N, Oh S, Konnikova L, Zemmour D, McGuire AM, et al. MUCOSAL IMMUNOLOGY. Individual Intestinal Symbionts Induce a Distinct Population of RORgamma(+) Regulatory T Cells. Science (2015) 349:993-7. doi: 10.1126/science.aaa9420

142. Lowther DE, Goods BA, Lucca LE, Lerner BA, Raddassi K, van Dijk D, et al. PD-1 Marks Dysfunctional Regulatory T Cells in Malignant Gliomas. JCI Insight (2016) 1:e85935-50. doi: 10.1172/jci.insight.85935

143. Vocanson M, Rozieres A, Hennino A, Poyet G, Gaillard V, Renaudineau S, et al Inducible Costimulator (ICOS) is a Marker for Highly Suppressive AntigenSpecific T Cells Sharing Features of TH17/TH1 and Regulatory T Cells. J Allergy Clin Immunol (2010) 126:280-9, 289 e1-7. doi: 10.1016/j.jaci.2010.05.022

144. Duhen T, Duhen R, Lanzavecchia A, Sallusto F, Campbell DJ. Functionally Distinct Subsets of Human FOXP3+ Treg Cells That Phenotypically Mirror Effector Th Cells. Blood (2012) 119:4430-40. doi: 10.1182/blood-2011-11-392324

145. Hoerning A, Koss K, Datta D, Boneschansker L, Jones CN, Wong IY, et al. Subsets of Human CD4(+) Regulatory T Cells Express the Peripheral Homing Receptor CXCR3. Eur J Immunol (2011) 41:2291-302. doi: 10.1002/eji.201041095

146. Lange C, Scholl M, Melms A, Bischof F. CD62L(High) Treg Cells With Superior Immunosuppressive Properties Accumulate Within the CNS During Remissions of EAE. Brain Behav Immun (2011) 25:120-6. doi: 10.1016/j.bbi.2010.09.004

147. Rubtsov YP, Rasmussen JP, Chi EY, Fontenot J, Castelli L, Ye X, et al. Regulatory $\mathrm{T}$ Cell-Derived interleukin-10 Limits Inflammation At Environmental Interfaces. Immunity (2008) 28:546-58. doi: 10.1016/j.immuni.2008.02.017

148. Sawant DV, Yano H, Chikina M, Zhang Q, Liao M, Liu C, et al. Adaptive Plasticity of IL-10(+) and IL-35(+) Treg Cells Cooperatively Promotes Tumor T Cell Exhaustion. Nat Immunol (2019) 20:724-35. doi: 10.1038/ s41590-019-0346-9

149. Duffy SS, Keating BA, Perera CJ, Lees JG, Tonkin RS, Makker PGS, et al. Interleukin-35, Reduce Pain in Experimental Autoimmune Encephalomyelitis. J Neurosci (2019) 39:2326-46. doi: 10.1523/JNEUROSCI.1815-18.2019

150. Turner JA, Stephen-Victor E, Wang S, Rivas MN, Abdel-Gadir A, Harb H, et al. Regulatory T Cell-Derived TGF-betal Controls Multiple Checkpoints Governing Allergy and Autoimmunity. Immunity (2020) 53:1202-14.e6. doi: 10.1016/j.immuni.2020.10.002

151. Sucher R, Fischler K, Oberhuber R, Kronberger I, Margreiter C, Ollinger R, et al. IDO and Regulatory $\mathrm{T}$ Cell Support are Critical for Cytotoxic $\mathrm{T}$ Lymphocyte-Associated Ag-4 Ig-Mediated Long-Term Solid Organ Allograft Survival. J Immunol (2012) 188:37-46. doi: 10.4049/jimmunol.1002777

152. Grossman WJ, Verbsky JW, Barchet W, Colonna M, Atkinson JP, Ley TJ. Human T Regulatory Cells can Use the Perforin Pathway to Cause Autologous Target Cell Death. Immunity (2004) 21:589-601. doi: 10.1016/ j.immuni.2004.09.002

153. Gondek DC, Lu LF, Quezada SA, Sakaguchi S, Noelle RJ. Cutting Edge: Contact-Mediated Suppression by CD4+CD25+ Regulatory Cells Involves a Granzyme B-dependent, Perforin-Independent Mechanism. J Immunol (2005) 174:1783-6. doi: 10.4049/jimmunol.174.4.1783

154. Deaglio S, Dwyer KM, Gao W, Friedman D, Usheva A, Erat A, et al. Adenosine Generation Catalyzed by CD39 and CD73 Expressed on Regulatory T Cells Mediates Immune Suppression. J Exp Med (2007) 204:1257-65. doi: 10.1084/jem.20062512

155. Park HJ, Park JS, Jeong YH, Son J, Ban YH, Lee BH, et al. PD-1 Upregulated on Regulatory $\mathrm{T}$ Cells During Chronic Virus Infection Enhances the Suppression of CD8+ T Cell Immune Response Via the Interaction With PD-L1 Expressed on CD8+ T Cells. J Immunol (2015) 194:5801-11. doi: 10.4049/jimmunol.1401936

156. Qureshi OS, Zheng Y, Nakamura K, Attridge K, Manzotti C, Schmidt EM, et al. Trans-Endocytosis of CD80 and CD86: A Molecular Basis for the 
Cell-Extrinsic Function of CTLA-4. Science (2011) 332:600-3. doi: 10.1126/ science.1202947

157. Ovcinnikovs V, Ross EM, Petersone L, Edner NM, Heuts F, Ntavli E, et al. Ctla-4-mediated Transendocytosis of Costimulatory Molecules Primarily Targets Migratory Dendritic Cells. Sci Immunol (2019) 4:aaw0902-14. doi: 10.1126/sciimmunol.aaw0902

158. Arpaia N, Green JA, Moltedo B, Arvey A, Hemmers S, Yuan S, et al. A Distinct Function of Regulatory T Cells in Tissue Protection. Cell (2015) 162:1078-89. doi: 10.1016/j.cell.2015.08.021

159. Nosbaum A, Prevel N, Truong HA, Mehta P, Ettinger M, Scharschmidt TC, et al. Cutting Edge: Regulatory T Cells Facilitate Cutaneous Wound Healing. J Immunol (2016) 196:2010-4. doi: 10.4049/jimmunol.1502139

160. Sharma A, Rudra D. Emerging Functions of Regulatory T Cells in Tissue Homeostasis. Front Immunol (2018) 9:883. doi: 10.3389/fimmu.2018.00883
161. Raffin C, Vo LT, Bluestone JA. Treg Cell-Based Therapies: Challenges and Perspectives. Nat Rev Immunol (2020) 20:158-72. doi: 10.1038/s41577-019$0232-6$

Conflict of Interest: The authors declare that the research was conducted in the absence of any commercial or financial relationships that could be construed as a potential conflict of interest.

Copyright (C) 2021 Selck and Dominguez-Villar. This is an open-access article distributed under the terms of the Creative Commons Attribution License (CC BY). The use, distribution or reproduction in other forums is permitted, provided the original author(s) and the copyright owner(s) are credited and that the original publication in this journal is cited, in accordance with accepted academic practice. No use, distribution or reproduction is permitted which does not comply with these terms. 